\title{
Silver nanoparticles as an alternative strategy against bacterial biofilms
}

\author{
Katarzyna Markowska ${ }^{凶}$, Anna M. Grudniak and Krystyna I. Wolska \\ Department of Bacterial Genetics, Institute of Microbiology, Faculty of Biology, University of Warsaw, Warsaw, Poland
}

\begin{abstract}
Biofilms are complex bacterial communities that resist the action of antibiotics and the human immune system. Bacteria within biofilms are the cause of numerous, almost impossible to eradicate, persistent infections. Biofilms can form on many medical devices and implants, and so have an enormous impact on medicine. Due to the lack of effective anti-biofilm antibiotics, novel alternative compounds or strategies are urgently required. This review describes some of the latest approaches in the field of biofilm treatment. New anti-biofilm technologies target different stages in the biofilm formation process. Some act to modify the colonized biomaterials to make them resistant to biofilm formation. One potentially important candidate treatment uses silver nanoparticles that show anti-bacterial and anti-biofilm activity. The biological action of nano-silver is complex and seems to involve a number of pathways. However, there have been few reports on the anti-biofilm activity of silver nanoparticles and the precise mechanism underlying their action remains unresolved. Here, we describe some anti-biofilm approaches employing AgNPs and consider the challenges and problems that need to be addressed in order to make silver nanoparticles a part of an effective anti-biofilm strategy.
\end{abstract}

Key words: biofilm, antibacterial, silver nanoparticles

Received: 30 October, 2013; revised: 02 December, 2013; accepted: 13 December, 2013; available on-line: 30 December, 2013

\section{INTRODUCTION}

In recent years, the number of infections associated with antibiotic-resistant bacteria has increased. Many of these infections are caused by microorganisms growing in biofilms. Both Gram-negative and Gram-positive bacteria can form biofilms on indwelling medical devices such as catheters, mechanical heart valves and prosthetic joints. The most common biofilm-forming bacteria associated with human disease are Enterococcus faecalis, Staphylococcus aureus, Staphylococcus epidermidis, Streptococcus viridans, Escherichia coli, Klebsiella pneumoniae, Proteus mirabilis and Pseudomonas aeruginosa (Donlan, 2001). Biofilm-related diseases are typically persistent infections characterized by slow development, an ability to resist host immune defenses and a transient response to antimicrobial therapy (Parsek \& Singh, 2003). Chronic infections are believed to be caused by a sub-population of cells within biofilms known as "persistent" that can survive prolonged antibiotic treatment and then detach from mature biofilms and spread to other organ systems (Lewis, 2010). The well known antibiotic resistance of biofilms may be caused by poor antibiotic penetration within the biofilm matrix, an altered microenvironment or an adaptive bacterial response. Such mechanisms acting together can raise the antibiotic resistance of biofilms by up to 1000 times in comparison with free living bacterial cells (for a review see Mah \& O'Toole, 2001). The aforementioned attributes of biofilms place them amongst the most serious problems currently facing medicine and considerable effort is being made to identify novel technologies that could form the basis of anti-biofilm therapies that are superior to current antibiotic treatment strategies. This review describes new approaches developed to prevent or treat biofilms, particularly focusing on the anti-biofilm activity of silver nanoparticles (AgNPs).

\section{BACTERIAL BIOFILMS}

Biofilms were first described by Antonie van Leeuwenhoek and they remain a subject of great interest to many researchers. Ongoing studies have greatly increased our knowledge of the genetic and physiological bases of biofilm formation and their structure for a wide range of bacteria. Various bacterial activities can influence the structure and attributes of biofilms, including cell growth or death, nutrient acquisition, waste product accumulation, motility mechanisms and exopolysaccharide synthesis (Karatan \& Watnick, 2009; Haussler \& Fuqua, 2013).

Biofilms represent bacterial communities embedded in self-produced extracellular polymeric matrix that is attached to a surface. The microbial population comprising a biofilm can be made up of single or multiple bacterial species. Bacteria develop biofilms on various surfaces such as natural aquatic systems, water pipes, living tissues, tooth surfaces, indwelling medical devices and implants (Donlan, 2002). The extracellular matrix is an intermediate environment for biofilm bacteria that stabilizes the three-dimensional biofilm structure and mediates bacterial adhesion (Flemming \& Wingender, 2010). The composition of the matrix, which directly affects the biofilm architecture, is controlled by enzymes secreted in response to nutrient availability (Gjermundsen et al., 2005).

Biofilm formation is initiated when bacterial cells attach and adhere to a surface. The switch between a planktonic and sessile lifestyle is associated with the recognition and transmission of particular signals from the environment. Signals favoring the early settlement of bacteria may include (i) the presence of an appropriate surface, (ii) increased levels of extracellular iron and fer-

e-mail: kgrzes@biol.uw.edu.pl

*Presented at the 3-rd Workshop on Microbiology "MIKROBIOT 2013" in Łódź, Poland.

Abbreviations: AgNPs, silver nanoparticles; c-di-GMP, cyclic diguanosine monophosphate; ROS, reactive oxygen species 
ritin that induce the biofilm phenotype in $P$. aeruginosa in the sputum of cystic fibrosis patients (Reid et al., 2002); (iii) the presence of compounds such as indole that stimulate biofilm formation of many Gram-negative bacteria (including E. coli, Klebsiella oxytoca, Citrobacter koseri), or other chemicals including polyamines, calcium or bile salts that modulate biofilm formation by Vibrio cholerae, Yersinia pestis, Pseudomonas putida and S. aureus (Di Martino et al., 2003; Kataran et al., 2005; Patel et al., 2006; Karatan \& Watnick, 2009). Bacteria recognize environmental signals by specific sensory systems: primarily two-component systems and the c-di-GMP-mediated signal transduction network. Two-component systems are not typically implicated in controlling the switch between planktonic and sessile lifestyles, but such systems are involved in the production of specific compounds that comprise the extracellular biofilm matrix. For a diverse group of bacterial species, the intracellular secondary messenger cyclic diguanosine monophosphate (c-di-GMP) has been implicated in the transition to the sessile form (Simm et al., 2004). It was suggested that the c-di-GMP signaling network is responsible for inhibiting cell motility and promoting biofilm development (Valle et al., 2013). However, some biofilm-forming bacteria lack the enzymes required for c-di-GMP synthesis and some species such as S. aureus and Listeria monocytogenes use c-di-AMP as an alternative secondary messenger (Woodward et al., 2010; Corrigan et al., 2011).

Adhesion of bacterial cells to surfaces may be facilitated by the production of multiple adhesive factors. Some species, e.g. $S$. aureus, produce adhesins that bind to host factors or plasma to mediate bacterial attachment to host tissues and implant surfaces (Menzies, 2003; Ní Eidhin et al., 1998). Bacterial attachment onto a surface becomes irreversible and this is accompanied by changes in the physiology, gene expression and protein profile of the cells. In the early stage of biofilm formation, the attached bacteria proliferate, aggregate and form characteristic microcolonies. Cells from the surrounding area are recruited, bind to existing structures and become embedded in extracellular matrix. The steps leading to biofilm development have been defined in detail (for a review see Kostakioti et al., 2013). The mature biofilm structure has a complex architecture and is permeated by channels. However, complicated biofilm structures, such as three-dimensional mushroom-shaped structures formed by $P$. aeruginosa, have so far been observed only in vitro (Deligianni et al., 2010). Within mature biofilm, the microbial community actively exchanges and shares products required to provide a favorable living environment for the bacteria in order to maintain the biofilm architecture. However, these structures are not static and cells may detach, leading to dispersion of the biofilm. Besides passive dispersal occurring as a result of shear stresses, bacteria have mechanisms that sense environmental changes and may be impelled to resume a planktonic lifestyle (Kostakioti et al., 2013). Subsequent stages of biofilm development are presented in Fig. 1.

Although a great deal is known about biofilm development, there are still unresolved questions concerning the initiation of biofilm formation on the surface of host tissues and the factors that determine the immune response towards the biofilm. Some recent studies have revealed that cyclic dinucleotides such as c-di-GMP, are recognized by the pattern-recognition receptors of the innate immune system, which activates type I interferon production by the host (McWhirter et al., 2009; Woodward et al., 2010; Blander \& Sander, 2012). The innate immunity is the first line of host defense against infection that recognizes and provides a rapid response to pathogens. It has been suggested that bacterial cyclic dinucleotides act as a signal of the presence of an incipient biofilm that triggers the immune response (Valle et al., 2013).

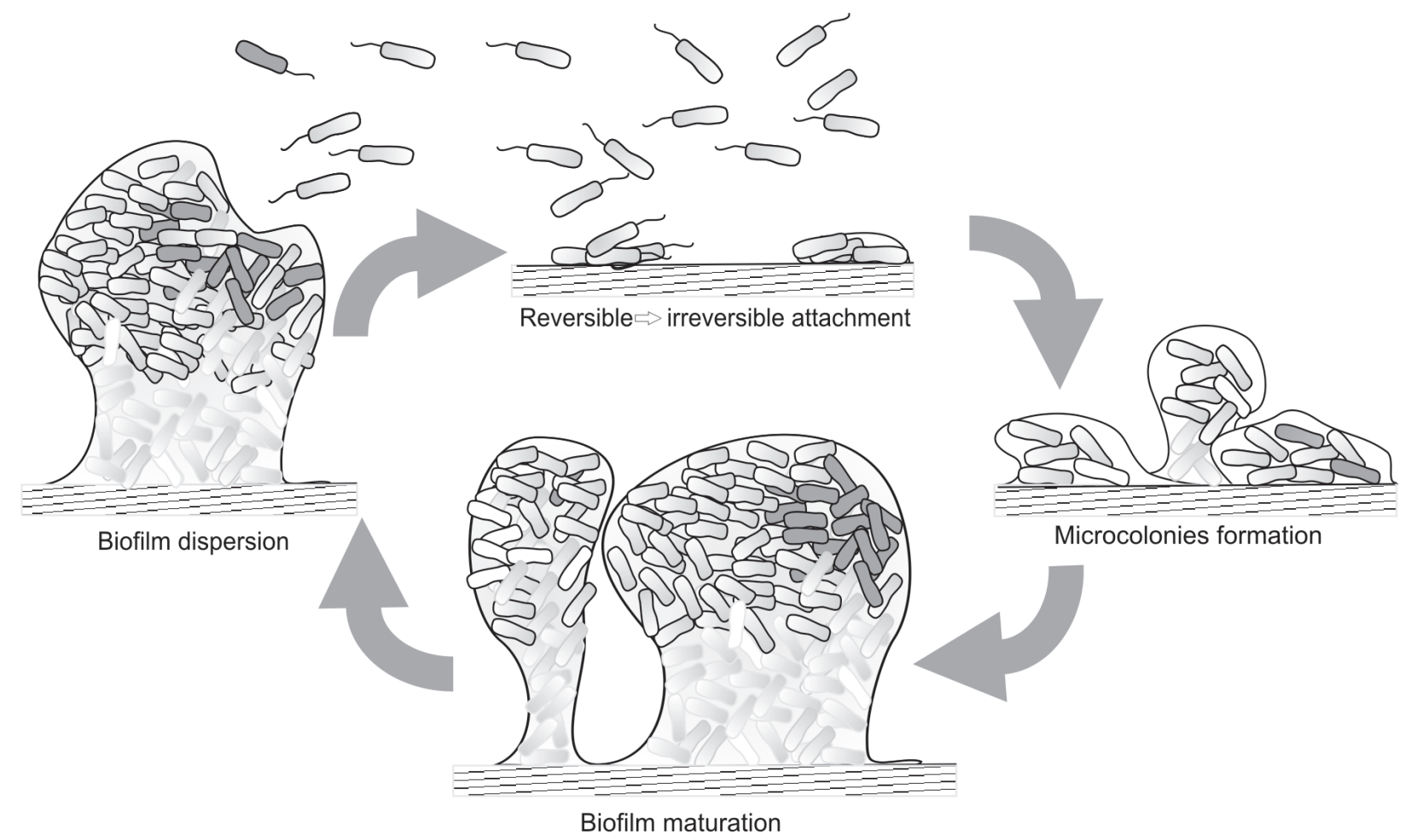

Figure 1. Subsequent stages of biofilm development. 


\section{NEW ANTI-BIOFILM STRATEGIES}

Due to the limited efficacy of antibiotics in preventing or treating biofilms, a number of alternative strategies has been devised. Chen and coworkers proposed the division of the new anti-biofilm technologies into two groups: (i) treatments that specifically inhibit the biofilm formation process and (ii) modified biomaterials for use in medical devices to make them resistant to biofilm formation (Chen et al., 2013). Examples of strategies designed to target different stages in biofilm formation are shown in Table 1. There are also numerous reports concerning new approaches to the design of devices with surfaces that are able to limit microbial adhesion and/or growth (for a review see Desrousseaux et al., 2013).

Large-scale screens that permit examination of a huge number of agents have been conducted to expedite the identification of compounds with anti-biofilm properties. High-throughput screening of small molecule libraries for novel bacterial biofilm formation inhibitors has identified a chemical series of molecules that inhibit the formation of or kill $S$. epidermidis or $V$. cholerae biofilms (Peach et al., 2011; Panmanee et al., 2013). New candidate compounds arising from the application of these large-scale screening techniques are likely to provide the basis for therapeutic agents that may be considered as alternatives to antibiotics after further examination.

One strategy for biofilm control that is currently receiving serious consideration is based on interference with bacterial cell-to-cell communication (quorum sensing). Because quorum sensing plays a vital role in infections caused by human, animal and plant pathogens, the identification of mechanisms that disrupt this system is a hot topic in microbiology. Quorum sensing inhibitors are likely to be effective in controlling bacterial infections, while having no effect on human cells (Defoirdt et al., 2013). A few studies have successfully applied highthroughput assays to identify inhibitors of quorum sensing (Christensen et al., 2013; Tan et al., 2013).

One class of compounds that show great promise as inhibitors of biofilm formation are anti-biofilm polysaccharides synthesized by bacteria. The first such polysaccharide was discovered in 2006 while studying interactions between uropathogenic and commensal strains of E. coli in mixed in vitro biofilms. It was found that the biomass of biofilms produced by the commensal strain was reduced in the presence of the uropathogenic strain (Valle et al., 2006). Recent studies have revealed the existence of polysaccharides that inhibit biofilm formation in a wide spectrum of bacteria and fungi grown both in vitro and in vivo (Rendueles et al., 2013).

Another approach to the control of biofilm formation is a bacteriophage therapy. Lytic phages may penetrate biofilm to directly infect and kill specific host bacteria or produce enzymes to degrade the exopolysaccharide matrix causing disruption of the biofilm structure (Donlan, 2009; Hanlon et al., 2001). A combination of phages and the chlorine disinfectant was successfully used in the control and removal of a $P$. aeruginosa biofilm (Zhang \& $\mathrm{Hu}$ 2013). Plant-derived compounds have been proved to be the other very promising anti-biofilm agents (for a review see Kurek et al., 2011).

Nanotechnological approaches to combat biofilm formation are based on the use of nanoparticles to functionalize the surface of biomaterials by coating (Roe et al., 2008; Applerot et al., 2012; Lellouche et al., 2012), impregnation (Flemming et al., 2000; Shi et al., 2006) or by embedding nanomaterials (Beyth et al., 2008). One such technology with great potential is generation by the use of sonochemistry of nano-antibiotics that are more active and more effective than classical antibiotics against drug-resistant pathogens. The reason for the increased efficacy of these nano-compounds is likely to be due to improved permeability through the cell envelope (Haussler \& Fuqua, 2013).

\section{ANTI-BIOFILM ACTIVITY OF SILVER NANOPARTICLES}

Among metal nanoparticles with proven antimicrobial activity, those made of silver are particularly effective bactericidal agents (Seil \& Webster, 2012). The antibacterial properties of silver have long been known and nanoparticles of this metal (AgNPs) are believed to be less toxic than silver ions. In recent years, the application of AgNPs in various fields has expanded considerably. AgNPs have been successfully used in medical and pharmaceutical nano-engineering for the delivery of therapeutic agents, in chronic disease diagnostics, and as part of sensors (Wong \& Liu, 2010; Thiwawong et al., 2013). The comparison of the various nano-silver activities that have been studied is difficult because of differences in the chemistry and physical properties of the particles employed. Furthermore the bactericidal effect of AgNPs is dependent on the size and shape of the particles (Panáček et al., 2006; Pal et al., 2007). The specific surface area of a dose of AgNPs increases as the particle size decreases, allowing greater material interaction with the surrounding environment. In addition, triangular-shaped particles of silver display more bacterial killing activity than rods or spherical particles (Pal et al., 2007). Other characteristics affecting the biological activity of nanoparticles are zeta potential and particle chemistry, with the former likely to play a significant role in the ability of particles to penetrate into the cell (Seil \& Webster, 2012).

Silver nanoparticles probably have multiple mechanisms of antibacterial action, but due to the current dearth of knowledge on this subject, the exact basis for the activity of AgNPs is still uncharacterized. Some studies have shown that $\mathrm{AgNPs}$ release $\mathrm{Ag}^{+}$ ions in the presence of water (Santoro et al., 2007; Asharani et al., 2008; Damm \& Münstedt, 2008). Lok and coworkers calculated that approximately $12 \%$ of the silver is present in the ionic form, tightly associated with the oxidation layer (Lok et al., 2007). However, their experimental design makes it difficult to distinguish between the mechanisms of action of AgNPs and dissolved $\mathrm{Ag}^{+}$ions. Hence, it was suggested that nano-silver affects bacterial membrane permeability by attaching to the cell membrane surface and modifying the cell potential. Observation of large numbers of nanoparticles inside bacteria suggests that this is important to the antibacterial mechanism (Morones et al., 2005). Proteomic analysis (2-DE and MS identification) of E. coli cells revealed that short-exposure to AgNPs resulted in the accumulation of envelope precursors, which is indicative of the dissipation of the proton motive force. Proteins whose expression was found to be stimulated by AgNPs over 1.8-fold were the inclusion body binding proteins $\mathrm{A}$ and $\mathrm{B}$ (IbpA and $\mathrm{IbpB}$ ), which serve as molecular chaperones, and 30S ribosomal subunit protein S6 (Lok et al., 2006). Furthermore, AgNPs have been shown to interact with bacterial membrane proteins, intracellular proteins, phosphate residues in DNA, and to interfere with cell division, leading to bacterial cell death (Sondi \& Salopek-Sondi, 2004; Xu et al., 2004). Presence 
of biocidal $\mathrm{Ag}^{+}$ions released from the nanoparticle surfaces evokes bacterial DNA conglomeration defense mechanisms, which protect the cell from toxic effects, but simultaneously compromises its replication ability. Thus microbial responses to ionic silver and nanoparticles are different, and knowledge of both is required for a complete understanding of the antibacterial activity of AgNPs. Some studies have reported that nano-silver causes oxidative damage, leading to the production of reactive oxygen species (ROS), i.e. free-radicals (Kim et al., 2007; Hwang et al., 2008), and it has been suggested that the production of ROS is one of the primary mechanisms of nanoparticle toxicity (Khan, 2012). Schematic representation of the effect of silver nanoparticles on microbial cell targets and biofilm formation is presented in the Fig. 2.

The anti-biofilm activity of silver nanoparticles has been demonstrated in a number of studies. Small but significant decreases in the biomass of 24-hour P. putida biofilms were observed by Fabrega and coworkers in the first report that discussed interactions between well quantified and characterized bacterial biofilms and silver nanoparticles (Fabrega et al., 2009). The average diameter of the AgNPs employed in this study $(65 \pm 30 \mathrm{~nm})$ was quite high considering that nanoparticles are within the range $1-100 \mathrm{~nm}$. Another study found that AgNPs (mean diameter $50 \mathrm{~nm}$ ) at a concentration of $100 \mathrm{nM}$ almost completely prevented biofilm formation by $P$. aeruginosa and $S$. epidermidis by impeding the initial step: bacterial adhesion to the surface (Kalishwaralal et al., 2010). More recent studies have tended to employ smaller AgNPs with greater biological activity. Nano-silver (average particle diameter $25.2 \pm 4 \mathrm{~nm}$ ) was found to effectively prevent the formation of $P$. aeruginosa biofilms and kill bacteria in established biofilm structures (4-log reduction in the number of colony-forming units), suggesting that it could be used for the prevention and treatment of biofilm-related infections (Martines-Gutierrez et al., 2013). Another recent study showed that AgNPs (average diameter $12.6 \pm 5.7 \mathrm{~nm}$ ) are also effective against Mycobacterium spp. biofilms. The colonization and growth of $M$. smegmatis biofilms on membranes coated with nano-silver at a concentration of $100 \mu \mathrm{M}$ were decreased by over $98.7 \%$. In addition, the presence of silver nanoparticles reduced survival of this bacterium to only $0.03 \%$ (Islam et al., 2013). It is important to note that differences in the chemical and physical properties of nano-silver used in the aforementioned studies may have caused some of the observed variation in its antimicrobial and anti-biofilm efficacy.

Because of the relatively low stability of colloidal solutions, some researchers propose the usage of stabilized AgNPs. This impedes the aggregation of particles into larger forms that can significantly decrease their activity. Radzig and colleagues found that AgNPs (about $8 \mathrm{~nm}$ in diameter), stabilized by hydrolyzed casein peptides, strongly inhibited biofilm formation by some Gram-negative bacteria. A decrease in the bacterial mass in biofilms of E. coli, P. aeruginosa and Serratia proteamaculans was observed when the AgNP concentration was between 5 and 10 micrograms per milliliter (Radzig et al., 2013). Mohanty et al. showed that starch-stabilized nanoparticles (about $20 \mathrm{~nm}$ in diameter), at very low concentrations of $1-2 \mathrm{mM}$, decreased $P$. aeruginosa and $S$. aureus biofilm formation by $65 \%$ and $88 \%$, respectively (Mohanty et al., 2012). Park and coworkers demonstrated the antimicrobial activity of citrate-capped silver nanoparticles (47 $\mathrm{nm}$ in diameter) against $P$. aeruginosa biofilms. Interestingly, they found that the inactivation of biofilms was greatly influenced by stirring. Therefore, these authors suggested that AgNPs inactivate biofilms in a biosorption-dependent manner (Park et al., 2013). The recent report

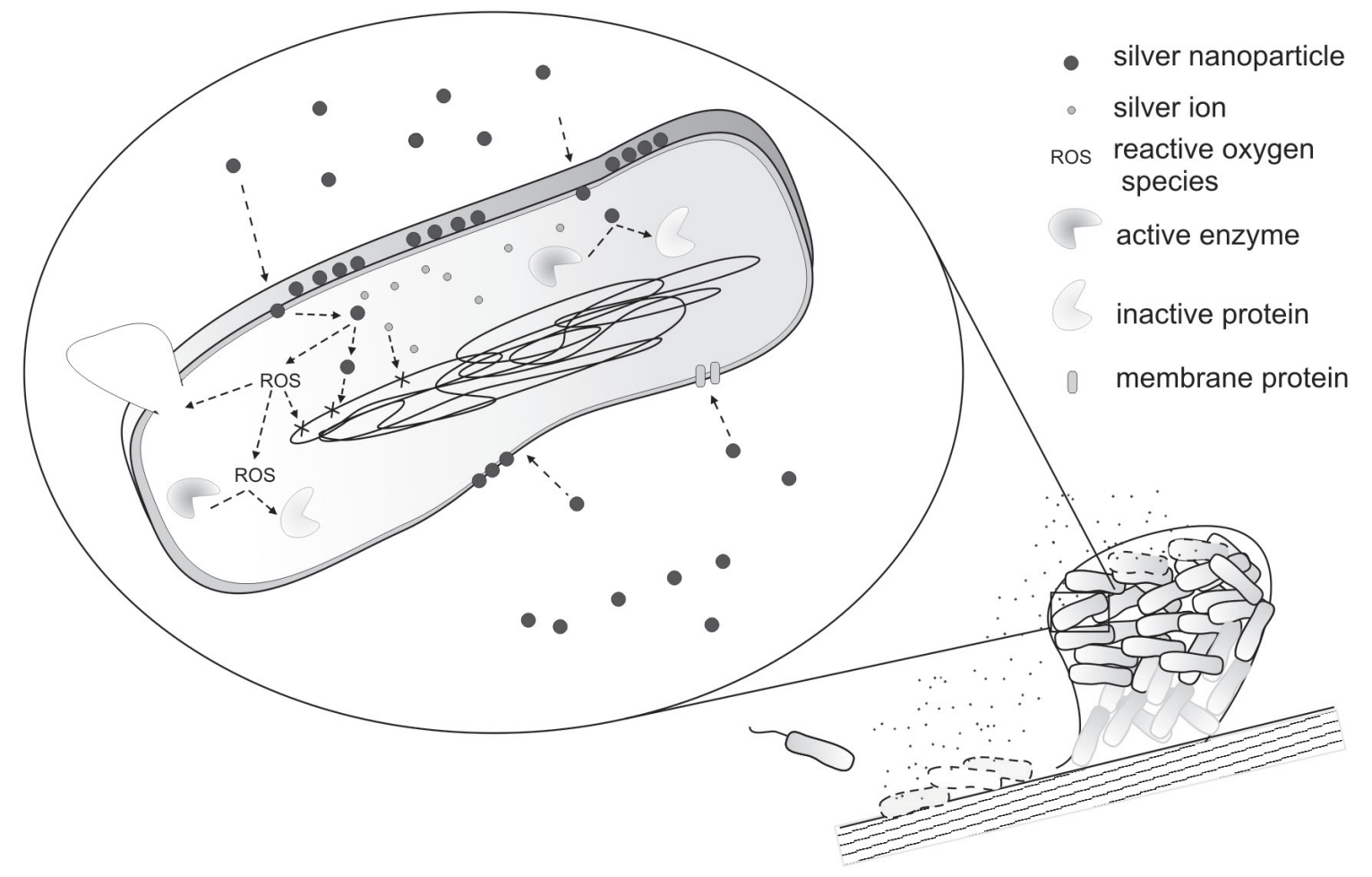

Figure 2. Schematic representation of the silver nanoparticle mechanism of action on the biofilm forming microbial cell. Description in the text. 
of Hartmann et al. introduced a new chip-calorimetric approach to detect bacterial metabolic changes with high resolution and reasonable throughput. With this system, they revealed a complete inhibition of the cell metabolic activity in a bead-grown biofilm of $P$. putida treated with commercially available silver nanoparticles (exact diameter not given) at a concentration of 0.5 micrograms per milliliter (Hartmann et al., 2013).

Silver nanoparticles, as it was previously shown, can also enhance the anti-bacterial and anti-biofilm activity of conventional antibiotics. There are reports describing synergistic activity between AgNPs and e.g. ampicillin, kanamycin, streptomycin or vancomycin against $E$. coli and $P$. aeruginosa (for review see Wolska et al., 2012). Additionally it was already demonstrated by our research group that nano-silver acts synergistically with streptomycin against $P$. aeruginosa (data not shown). Other studies have revealed synergy of AgNPs with compounds other than antibiotics. For example Ammons et al. (2011) showed that a silver wound dressing combined with the immune molecule lactoferrin and the rare sugar-alcohol xylitol, reduced biofilm viability more effectively than standard silver hydrogel.

As mentioned above, some new anti-biofilm approaches are based on the coating of medical devices or improvement of the properties of biomaterials. Silver has been proposed as a component of coatings that may have potential in combating biofilm formation. Roe and coworkers examined the efficacy of nano-silver (mean average diameter of $10 \mathrm{~nm}$ ) as an anti-biofilm agent used to coat the surface of catheters (Roe et al., 2008). Notable anti-biofilm effects against Gram-positive and Gram-negative bacteria, and also Candida albicans, were found when catheters coated with AgNPs were tested in vitro. After 72 hours of incubation, these authors observed almost complete prevention of biofilm formation by $E$. coli, $S$. aureus and C. albicans, and more than $50 \%$ inhibition in the case of Enterococcus sp., coagulase-negative staphylococci and $P$. aeruginosa. In addition, no significant accumulation of silver was detected in the major organs of mice fitted with the treated catheters, suggesting that these are non-toxic devices that permit the targeted and sustained release of bactericidal silver at the implantation site (Roe et al., 2008). Subsequently Cheng and coworkers created dental composites containing silver nanoparticles that can kill oral bacteria such as S. mutans. These new nanocomposites significantly reduced the metabolic activity and lactic acid production of $S$. mutans biofilms, when compared with two commercial composites (Cheng et al., 2012).

Besides the aforementioned primary studies of the anti-biofilm effects of AgNPs, some nano-silver-coated medical devices are already at the stage of clinical trials. The most prominent examples are catheters, drains and wound dressings containing silver nanoparticles. Some studies have confirmed the beneficial effect of nano-silver as a component of coatings (Knetsch \& Koole, 2011). Two reports evaluating large prospective randomized studies emphasize the promising outcome of trials with biomaterials containing nano-silver (Lackner et al., 2008; Gravante \& Montone, 2010). In some cases the successful use of silver nanoparticles has already been confirmed, e.g. for coating surgical masks (Li et al., 2006). The impregnation of such medical devices with silver nanoparticles has the advantage that it protects both the outer and inner surfaces, providing continuous antimicrobial activity.

\section{CHALLENGES FOR THE ANTI-BIOFILM APPLICATION OF SILVER NANOPARTICLES}

The application of silver nanoparticles as an effective antimicrobial agent should not cause microbial resist-

Table 1. Examples of new strategies to inhibit or disrupt biofilms at different stages of their development.

\begin{tabular}{|c|c|c|}
\hline Stage of biofilm development & Strategy to inhibit or disrupt biofilm formation & Reference \\
\hline \multirow{3}{*}{$\begin{array}{l}\text { Reversible/irreversible attach- } \\
\text { ment }\end{array}$} & Anti-adhesion agents, e.g. mannoside, pilicides, curlicides & $\begin{array}{l}\text { Han et al., } 2010 \\
\text { Cegelski et al., } 2009\end{array}$ \\
\hline & Anti-biofilm polysaccharides & Rendueles et al., 2013 \\
\hline & $\begin{array}{l}\text { Signal transduction interference, e.g. quorum sensing and } \\
\text { two-component signaling }\end{array}$ & $\begin{array}{l}\text { Roy et al., } 2013 \\
\text { Gotoh et al., } 2010\end{array}$ \\
\hline \multirow{7}{*}{$\begin{array}{l}\text { Microcolony formation and bio- } \\
\text { film maturation }\end{array}$} & Silver nanoparticles & Kalishwaralal et al., 2010 \\
\hline & Lytic phages & Carson et al., 2010 \\
\hline & Enzymes degrading extracellular matrix, e.g. Dispersin B & Lu \& Collins, 2007 \\
\hline & Anti-biofilm polysaccharides & Rendueles et al., 2013 \\
\hline & Antimicrobial peptides & $\begin{array}{l}\text { Pompillo et al., 2011; } \\
\text { Kharidia \& Liang, } 2011\end{array}$ \\
\hline & $\begin{array}{l}\text { Signal transduction interference, e.g. quorum sensing and } \\
\text { two-component signaling }\end{array}$ & $\begin{array}{l}\text { Roy et al., } 2013 \\
\text { Gotoh et al., } 2010\end{array}$ \\
\hline & Chelating agents & $\begin{array}{l}\text { Percival et al., 2005b; } \\
\text { Shanks et al., 2006; } \\
\text { Abraham et al., } 2012\end{array}$ \\
\hline \multirow[b]{2}{*}{ Dispersion } & c-di-GMP engineering to promote motility vs. sessility & Ma et al., 2011 \\
\hline & $\begin{array}{l}\text { Introduction of dispersal signals, e.g. D-amino acids, nor- } \\
\text { spermidine }\end{array}$ & $\begin{array}{l}\text { Kolodkin-Gal et al., 2010; Kolodkin-Gal } \\
\text { et al., } 2012\end{array}$ \\
\hline
\end{tabular}


ance even after long-term usage. However, there have been reports concerning bacterial resistance to silver compounds determined by genes carried on plasmids. The resistance mechanism involves a periplasmic multimetal-binding protein, a chemiosmotic efflux pump and an ATPase efflux pump encoded by a single toxic metal cation resistance gene cluster (Silver, 2003). Resistance is conferred by the action of plasmid-encoded pumps that promote the active efflux of $\mathrm{Ag}^{+}$ions out of the cell. The widespread usage of silver nanoparticles (e.g. as a component of disinfectants) might promote the spread of silver-resistant bacterial strains. However, prolonged exposure of bacteria to silver nanoparticles has not resulted in the development of resistant mutant cells. Silver nanoparticles as biocides tend to target multiple sites on or within bacterial cells and hence have broadspectrum activity. Furthermore, this property of AgNPs means that they can overcome existing microbial drug resistance mechanisms, including decreased uptake and increased efflux from the microbial cell, and biofilm formation (Pelgrift \& Friedman, 2013). The evolution of silver resistance seems to be slow and this problem is less of a concern than resistance to other antibacterial agents (Percival et al., 2005a).

It should be noted that there also have been some disappointing clinical trials of medical devices coated with nano-silver (Knetsch \& Koole, 2011). One shortcoming of bactericidal surfaces is that their antimicrobial function may be negated if they become covered by macromolecules or dead microorganisms. Another problem is the reduced efficacy of metallic silver on medical devices contacting the blood, as the coating wears off (Rai et al., 2009). Therefore improved methods of coating or incorporating $\mathrm{AgNPs}$ are required to prolong the efficacy of such devices. On the other hand, there are reports confirming that biofilm formation is almost completely prevented on catheters coated with nano-silver (Knetsch \& Koole, 2011; Chen et al., 2013).

In depth knowledge concerning the biocompatibility of silver nanoparticles is essential before they become widely used as coating for medical devices or incorporated into biomaterials. The interaction between nano-silver and the human body will determine the clinical success of medical devices containing AgNPs. The biosafety of silver nanoparticles is currently uncertain. Some of the mechanisms mediating the biological activity of AgNPs are not specific for the cells of bacteria or fungi, but are conserved in many organisms, potentially also in humans. So far, there have been very few reports on the effects of AgNPs on human health, although some studies have revealed in vivo bio-distribution and toxicity in rats and mice. AgNPs administered by inhalation, ingestion or injection were subsequently detected in the blood and caused toxicity in several organs including the brain (for a review see Ahamed et al., 2010). However, other reports suggested that the toxicity of nano-silver for mammalian cells is low. In experiments using therapeutic doses of silver nanoparticles, only very low levels (below 0.5 micrograms per gram of an organ) could be detected in the organs of mice, suggesting that nano-silver is safe at these low concentrations (Wong \& Liu, 2010). Other studies have confirmed the dose-dependent toxicity of nanoparticles. Lee et al. recently demonstrated unambiguous stage- and dose-dependent toxic effects of AgNPs on embryonic development in zebrafish (Lee et al., 2013). Another report implied that AgNPs at high doses could have genotoxic and cytotoxic effects on human cells (Jena et al., 2012). In in vitro experiments, Park and coworkers showed that the potency of silver nanoparti- cles to induce cell damage, compared to silver ions, is cell type and size-dependent (Park et al., 2011). Another recent study revealed the dose-dependent influence of $\mathrm{AgNPs}$ on the bioactivity of bone-forming cells and the possibility of nanoparticle uptake by human mesenchymal stem cells and human osteoblasts (Pauksch et al., 2014). In clinical practice, features such as wound exudation might increase the applicability of silver nanoparticles, because the high protein content of such exudates is likely to neutralize nano-silver tissue toxicity (Wong \& Liu, 2010). Undoubtedly the possible side effects of nanoparticles have not received sufficient attention and detailed studies are urgently required before the clinical use of AgNPs is approved.

\section{CONCLUSIONS}

Bacterial biofilms are a serious medical problem. Due to the increasing ineffectiveness of conventional antibiotics, numerous alternative methods to combat bacterial biofilms are being considered. Silver nanoparticles have recently received an increased attention for their antimicrobial effects and possible clinical applications. Despite numerous studies conducted over the last decade there are still considerable gaps in our knowledge about the antimicrobial properties of AgNPs. Furthermore, the precise basis of their antibacterial activity has yet to be defined. This is mainly due to the pleiotropic effects of nano-silver on bacterial cells, which suggests multiple mechanisms of action on several cellular targets. Nonetheless, the strong anti-biofilm effect of AgNPs is indisputable. Several studies have demonstrated the inhibition of in vitro biofilm formation by a variety of bacterial species at specific nanoparticle concentrations. This raises the intriguing possibility of treating infections caused by biofilm-forming bacteria with AgNPs. However, the toxicity of nanoparticles to eukaryotic cells is a legitimate concern and still remains uncharacterized. One way of avoiding this potential drawback might be to target AgNPs to the specific site of an infection so that toxic silver concentrations are localized. In addition, improvements in the way that AgNPs are incorporated into medical devices could increase their efficacy and diminish any side-effects, but considerable research effort is still required to perfect this technology.

\section{REFERENCES}

Abraham NM, Lamlertthon S, Fowler VG, Jefferson KK (2012) Chelating agents exert distinct effects on biofilm formation in Staphylococcus aureus depending on strain background: role for clumping factor B. I Med Microbiol 61: 1062-1070.

Ahamed M, AlSalhi MS, Siddiqui MKJ (2010) Silver nanoparticle applications and human health. Clin Chim Acta 411: 1841-1848.

Ammons MCB, Ward LS, James GA (2011) Anti-biofilm efficacy of a lactoferrin/xylitol wound hydrogel used in combination with silver wound dressings. Int Wound J 8: 268-273.

Applerot G, Lellouche J, Perkas N, Nitzan Y Gedanken A, Banin E (2012) ZnO nanoparticle-coated surfaces inhibit bacterial biofilm formation and increase antibiotic susceptibility. RSC Advances 2: 2314.

Asharani PV, Lian Wu Y, Gong Z, Valiyaveettil S (2008) Toxicity of silver nanoparticles in zebrafish models. Nanotechnology 19: 255102.

Beyth N, Houri-Haddad Y, Baraness-Hadar L, Yudovin-Farber I, Domb AJ, Weiss EI (2008) Surface antimicrobial activity and biocompatibility of incorporated polyethylenimine nanoparticles. Biomaterials 29: 4157-4163.

Blander JM, Sander LE (2012) Beyond pattern recognition: five immune checkpoints for scaling the microbial threat. Nat Rev Immunol 12: $215-225$.

Carson L, Gorman SP, Gilmore BF (2010) The use of lytic bacteriophages in the prevention and eradication of biofilms of Proteus mirabilis and Escherichia coli. FEMS Immunol Med Microbiol 59: 447-455. 
Cegelski L, Pinkner JS, Hammer ND, Cusumano CK, Hung CS, Chorell E, Aberg V, Walker JN, Seed PC, Almqvist F, Chapman MR, Hultgren SJ (2009) Small-molecule inhibitors target Escherichia coli amyloid biogenesis and biofilm formation. Nat Chem Biol 5: 913-919.

Chen M, Yu Q, Sun H (2013) Novel Strategies for the prevention and treatment of biofilm related infections. Int J Mol Sci 14: 8488-18501.

Cheng L, Weir MD, Xu HHK, Antonucci JM, Kraigsley AM, Lin NJ, Lin-Gibson S, Zhou X (2012) Antibacterial amorphous calcium phosphate nanocomposites with a quaternary ammonium dimethacrylate and silver nanoparticles. Dent Mater 28: 561-572.

Christensen QH, Grove TL, Booker SJ, Greenberg EP (2013) A highthroughput screen for quorum-sensing inhibitors that target acylhomoserine lactone synthases. PNAS 110: 13815-13820.

Corrigan RM, Abbott JC, Burhenne H, Kaever V, Gründling A (2011) c-di-AMP is a new second messenger in Staphylococcus aureus with a role in controlling cell size and envelope stress. PLoS Pathog 7: e1002217.

Damm C, Münstedt H (2008) Kinetic aspects of the silver ion release from antimicrobial polyamide/silver nanocomposites. Appl Phys A Mater Sci Process 91: 479-486.

Defoirdt T, Brackman G, Coenye T (2013) Quorum sensing inhibitors: how strong is the evidence? Trends Microbiol 12: 619-24.

Deligianni E, Pattison S, Berrar D, Ternan NG, Haylock RW, Moore JE, Elborn SJ, Dooley JS (2010) Pseudomonas aeruginosa cystic fibrosis isolates of similar RAPD genotype exhibit diversity in biofilm forming ability in vitro. BMC Microbiol 10: 38.

Desrousseaux C, Sautou V, Descamps S, Traoré O (2013) Modification of the surfaces of medical devices to prevent microbial adhesion and biofilm formation. J Hosp Infect 85: 87-93.

Donlan RM (2001) Biofilms and device-associated infections. Emerg Infect Dis 7: 277-281.

Donlan RM (2002) Biofilms: microbial life on surfaces. Emerg Infect Dis 8: 881-890.

Donlan RM (2009) Preventing biofilms of clinically relevant organisms using bacteriophage. Trends Microbiol 17: 66-72.

Fabrega J, Renshaw JC, Lead JR (2009) Interactions of silver nanoparticles with Pseudomonas putida biofilms. Environ Sci Technol 43: 9004 9009.

Flemming H-C, Wingender J (2010) The biofilm matrix. Nat Rev Micro 8: $623-633$.

Flemming RG, Capelli CC, Cooper SL, Proctor RA (2000) Bacterial colonization of functionalized polyurethanes. Biomaterials 21: 273281.

Gjermansen M, Ragas P, Sternberg C, Molin Søren, Tolker-Nielsen Tim (2005) Characterization of starvation-induced dispersion in Pseudomonas putida biofilms. Environ Microbiol 7: 894-906.

Gotoh Y, Eguchi Y, Watanabe T, Okamoto S, Doi A, Utsumi R (2010) Two-component signal transduction as potential drug targets in pathogenic bacteria. Curr Opin Microbiol 13: 232-239.

Gravante G, Montone A (2010) A retrospective analysis of ambulatory burn patients: focus on wound dressings and healing times. Ann R Coll Surg Engl 92: 118-123.

Han Z, Pinkner JS, Ford B, Obermann R, Nolan W, Wildman SA, Hobbs D, Ellenberger T, Cusumano C, Hultgren SJ, Janetka JW (2010) Structure-based drug design and optimization of mannoside bacterial FimH antagonists. J Med Chem 53: 4779-4792.

Hanlon GW, Denyer SP, Olliff CJ, Ibrahim LJ (2001) Reduction in exopolysaccharide viscosity as an aid to bacteriophage penetration through Pseudomonas aeruginosa biofilms. Appl Environ Microbiol 67: 2746-2753.

Hartmann T, Mühling M, Wolf A, Mariana F, Maskow T, Mertens F, Neu TR, Lerchner J (2013) A chip-calorimetric approach to the analysis of $\mathrm{Ag}$ nanoparticle caused inhibition and inactivation of beads-grown bacterial biofilms. J Microbiol Methods 95: 129-137.

Haussler S, Fuqua C (2013) Biofilms 2012: New discoveries and significant wrinkles in a dynamic field. I Bacteriol 195: 2947-2958.

Hwang ET, Lee JH, Chae YJ, Kim YS, Kim BC, Sang BI, Gu MB (2008) Analysis of the toxic mode of action of silver nanoparticles using stress-specific bioluminescent bacteria. Small 4: 746-750.

Islam MS, Larimer C, Ojha A, Nettleship I (2013) Antimycobacterial efficacy of silver nanoparticles as deposited on porous membrane filters. Mater Sci Eng C Mater Biol Appl 33: 4575-4581.

Jena P, Mohanty S, Mallick R, Jacob B, Sonawane A (2012) Toxicity and antibacterial assessment of chitosancoated silver nanoparticles on human pathogens and macrophage cells. Int I Nanomedicine 7: 1805-1818.

Kalishwaralal K, BarathManiKanth S, Pandian SRK, Deepak V, Gurunathan S (2010) Silver nanoparticles impede the biofilm formation by Pseudomonas aeruginosa and Staphylococcus epidermidis. Colloids and Surfaces B: Biointerfaces 79: 340-344.

Karatan E, Duncan TR, Watnick PI (2005) NspS, a predicted polyamine sensor, mediates activation of Vibrio cholerae biofilm formation by norspermidine. J Bacteriol 187: 7434-7443.
Karatan E, Watnick P (2009) Signals, regulatory networks, and materials that build and break bacterial biofilms. Microbiol Mol Biol Rev 73: $310-347$.

Khan AU (2012) Medicine at nanoscale: a new horizon. Int J Nanomedicine 7: 2997-2998.

Kharidia R, Liang JF (2011) The activity of a small lytic peptide PTP-7 on Staphylococcus aureus biofilms. I Microbiol 49: 663-668.

Kim JS, Kuk E, Yu KN, Kim JH, Park SJ, Lee HJ, Kim SH, Park JK, Park YH, Hwang CY, Kim YK, Lee YS, Jeong DH, Cho MH (2007) Antimicrobial effects of silver nanoparticles. Nanomed-Nanotechnol 3: 95-101.

Knetsch MLW, Koole LH (2011) New strategies in the development of antimicrobial coatings: the example of increasing usage of silver and silver nanoparticles. Polymers 3: 340-366.

Kolodkin-Gal I, Cao S, Chai L, Böttcher T, Kolter R, Clardy J, Losick R (2012) A self-produced trigger for biofilm disassembly that targets exopolysaccharide. Cell 149: 684-692.

Kolodkin-Gal I, Romero D, Cao S, Clardy J, Kolter R, Losick R (2010) D-amino acids trigger biofilm disassembly. Science 328: 627-629.

Kostakioti M, Hadjifrangiskou M, Hultgren SJ (2013) Bacterial biofilms: development, dispersal, and therapeutic strategies in the dawn of the postantibiotic era. Cold Spring Harb Perspect Med 3: a010306.

Kurek A, Grudniak AM, Kraczkiewicz-Dowjat A, Wolska KI (2011) New antibacterial therapeutics and strategies. Pol J Microbiol 60: 3-12.

Lackner P, Beer R, Broessner G, Helbok R, Galiano K, Pleifer C, Pfausler B, Brenneis C, Huck C, Engelhardt K, Obwegeser AA, Schmutzhard E (2008) Efficacy of silver nanoparticles-impregnated external ventricular drain catheters in patients with acute occlusive hydrocephalus. Neurocrit Care 8: 360-365.

Lee KJ, Browning LM, Nallathamby PD, Osgood CJ, Xu XH (2013) Silver nanoparticles induce developmental stage-specific embryonic phenotypes in zebrafish. Nanoscale 5: 11625-36.

Lellouche J, Friedman A, Gedanken A, Banin E (2012) Antibacteri$\mathrm{al}$ and antibiofilm properties of yttrium fluoride nanoparticles. Int $J$ Nanomedicine 7: 5611-5624.

Lewis K (2010) Persister cells. Ann Rev Microbiol 64: 357-372.

Li Y, Leung P, Yao L, Song QW, Newton E (2006) Antimicrobial effect of surgical masks coated with nanoparticles. J Hosp Infect 62: $58-63$.

Lok C-N, Ho C-M, Chen R, He QY, Yu WY, Sun H, Tam PK, Chiu JF, Che CM (2006) Proteomic analysis of the mode of antibacterial action of silver nanoparticles. J Proteome Res 5: 916-924.

Lok C-N, Ho C-M, Chen R, He QY, Yu WY, Sun H, Tam PK, Chiu JF, Che CM (2007) Silver nanoparticles: partial oxidation and antibacterial activities. I Biol Inorg Chem 12: 527-534.

Lu TK, Collins JJ (2007) Dispersing biofilms with engineered enzymatic bacteriophage. Proc Natl Acad Sci USA 104: 11197-11202.

Ma Q, Yang Z, Pu M, Peti W, Wood TK (2011) Engineering a novel c-di-GMP-binding protein for biofilm dispersal. Environ Microbiol 13: 631-642.

Mah T-FC, O’Toole GA (2001) Mechanisms of biofilm resistance to antimicrobial agents. Trends Microbiol 9: 34-39.

Martinez-Gutierrez F, Boegli L, Agostinho A, Sánchez EM, Bach H, Ruiz F, James G (2013) Anti-biofilm activity of silver nanoparticles against different microorganisms. Biofouling 29: 651-660.

Di Martino P, Fursy R, Bret L, Sundararaju B, Phillips RS (2003) Indole can act as an extracellular signal to regulate biofilm formation of Escherichia coli and other indole-producing bacteria. Can J Microbiol 49: 443-449.

McWhirter SM, Barbalat R, Monroe KM, Fontana MF, Hyodo M, Joncker NT, Ishii KJ, Akira S, Colonna M, Chen ZJ, Fitzgerald KA, Hayakawa Y, Vance RE (2009) A host type I interferon response is induced by cytosolic sensing of the bacterial second messenger cyclic-di-GMP. J Exp Med 206: 1899-1911.

Menzies BE (2003) The role of fibronectin binding proteins in the pathogenesis of Staphylococcus aureus infections. Curr Opin Infect Dis 16: $225-229$.

Mohanty S, Mishra S, Jena P, Jacob B, Sarkar B, Sonawane A (2012) An investigation on the antibacterial, cytotoxic, and antibiofilm efficacy of starch-stabilized silver nanoparticles. Nanomed-Nanotechnol 8: 916-924.

Morones JR, Elechiguerra JL, Camacho A, Holt K, Kouri JB, Ramírez JT, Yacaman MJ (2005) The bactericidal effect of silver nanoparticles. Nanotechnology 16: 2346.

Ní Eidhin D, Perkins S, Francois P, Vaudaux P, Höök M, Foster TJ (1998) Clumping factor B (ClfB), a new surface-located fibrinogen-binding adhesin of Staphylococcus aureus. Mol Microbiol 30: 245257.

Pal S, Tak YK, Song JM (2007) Does the antibacterial activity of silver nanoparticles depend on the shape of the nanoparticle? A study of the Gram-negative bacterium Escherichia coli. Appl Environ Microbiol 73: $1712-1720$.

Panáček A, Kvítek L, Prucek R, Kolar M, Vecerova R, Pizúrova N, Sharma VK, Nevecna T, Zboril R (2006) Silver colloid nanopar- 
ticles: synthesis, characterization, and their antibacterial activity. $J$ Phys Chem B 110: 16248-16253.

Panmanee W, Taylor D, Shea CJA, Tang H, Nelson S, Seibel W, Papoian R, Kramer R, Hassett DJ, Lamkin TJ (2013) High-throughput screening for small-molecule inhibitors of Staphylococcus epidermidis RP62a biofilms. J Biomol Screen 1087057113481499.

Park HJ, Park S, Roh J, Kim S, Choi K, Yi J, Kim J, Yoon J (2013) Biofilm-inactivating activity of silver nanoparticles: A comparison with silver ions. J Ind Eng Chem 19: 614-619.

Park MV, Neigh AM, Vermeulen JP, de la Fonteyne LJ, Verharen HW, Briedé JJ, van Loveren H, de Jong WH (2011) The effect of particle size on the cytotoxicity, inflammation, developmental toxicity and genotoxicity of silver nanoparticles. Biomaterials 32: 9810-9817.

Parsek MR, Singh PK (2003) Bacterial biofilms: An emerging link to disease pathogenesis. Annu Rev Microbiol 57: 677-701.

Patel CN, Wortham BW, Lines JL, Fetherston JD, Perry RD, Oliveira MA (2006) Polyamines are essential for the formation of plague biofilm. I Bacteriol 188: 2355-2363.

Pauksch L, Hartmann S, Rohnke M, Szalay G, Alt V, Schnettler R, Lips KS (2014) Biocompatibility of silver nanoparticles and silver ions in primary human mesenchymal stem cells and osteoblasts. Acta Biomaterialia 10: 439-49.

Peach KC, Bray WM, Shikuma NJ, Gassner NC, Lokey RS, Yildiz FH, Linington RG (2011) An image-based 384-well high-throughput screening method for the discovery of biofilm inhibitors in Vibrio cholerae. Mol Biosyst 7: 1176.

Pelgrift RY, Friedman AJ (2013) Nanotechnology as a therapeutic tool to combat microbial resistance. Adv Drug Deliv Rev 65: 1803-15.

Percival SL, Bowler PG, Russell D (2005a) Bacterial resistance to silver in wound care. J Hosp Infect 60: 1-7.

Percival SL, Kite P, Eastwood K, Murga R, Carr J, Arduino MJ, Donlan RM (2005b) Tetrasodium EDTA as a novel central venous catheter lock solution against biofilm. Infect Control Hosp Epidemiol 26: 515-519.

Pompilio A, Scocchi M, Pomponio S, Guida F, Di Primio A, Fiscarelli E, Gennaro R, Di Bonaventura G (2011) Antibacterial and anti-biofilm effects of cathelicidin peptides against pathogens isolated from cystic fibrosis patients. Peptides 32: 1807-1814.

Radzig MA, Nadtochenko VA, Koksharova OA, Kiwi J, Lipasova VA, Khmel IA (2013) Antibacterial effects of silver nanoparticles on gram-negative bacteria: Influence on the growth and biofilms formation, mechanisms of action. Colloids and Surfaces B: Biointerfaces 102: 300-306.

Rai M, Yadav A, Gade A (2009) Silver nanoparticles as a new generation of antimicrobials. Biotechnol Adv 27: 76-83.

Reid DW, Withers NJ, Francis L, Wilson JW, Kotsimbos TC (2002) Iron deficiency in cystic fibrosis: Relationship to lung disease severity and chronic Pseudomonas aeruginosa infection. Chest 121: 48-54.

Rendueles O, Kaplan JB, Ghigo J-M (2013) Antibiofilm polysaccharides. Environ Microbiol 15: 334-346.

Roe D, Karandikar B, Bonn-Savage N, Gibbins B, Roullet JB (2008) Antimicrobial surface functionalization of plastic catheters by silver nanoparticles. J Antimicrob Chemother 61: 869-876.
Roy V, Meyer MT, Smith JAI, Gamby S, Sintim HO, Ghodssi R, Bentley WE. (2013) AI-2 analogs and antibiotics: a synergistic approach to reduce bacterial biofilms. Appl Microbiol Biotechnol 97: 2627-2638.

Santoro CM, Duchsherer NL, Grainger DW (2007) Minimal in vitro antimicrobial efficacy and ocular cell toxicity from silver nanoparticles. Nanobiotechnology 3: 55-65.

Seil JT, Webster TJ (2012) Antimicrobial applications of nanotechnology: methods and literature. Int J Nanomedicine 7: 2767-2781.

Shanks RMQ, Sargent JL, Martinez RM, Graber ML, O’Toole GA (2006) Catheter lock solutions influence staphylococcal biofilm formation on abiotic surfaces. Nephrol Dial Transplant 21: 2247-2255.

Shi Z, Neoh KG, Kang ET, Wang W (2006) Antibacterial and mechanical properties of bone cement impregnated with chitosan nanoparticles. Biomaterials 27: 2440-2449.

Silver S (2003) Bacterial silver resistance: molecular biology and uses and misuses of silver compounds. FEMS Microbiol Rev 27: 341-353.

Simm R, Morr M, Kader A, Nimtz M, Römling U (2004) GGDEF and EAL domains inversely regulate cyclic di-GMP levels and transition from sessility to motility. Mol Microbiol 53: 1123-1134.

Sondi I, Salopek-Sondi B (2004) Silver nanoparticles as antimicrobial agent: a case study on E. coli as a model for Gram-negative bacteria. J Colloid Interface Sci 275: 177-182.

Tan SY-Y, Chua S-L, Chen Y, Rice SA, Kjelleberg S, Nielsen TE, Yang L, Givskov M (2013) Identification of five structurally unrelated quorum-sensing inhibitors of Pseudomonas aeruginosa from a natural-derivative database. Antimicrob Agents Chemother 57: 5629-5641.

Thiwawong T, Onlaor K, Tunhoo B (2013) A humidity sensor based on silver nanoparticles thin film prepared by electrostatic spray deposition process. Adv Mater Sci Eng. doi: 10.1155/2013/640428.

Valle J, Da Re S, Henry N, Fontaine T, Balestrino D, Latour-Lambert P, Ghigo JM. (2006) Broad-spectrum biofilm inhibition by a secreted bacterial polysaccharide. Proc Natl Acad Sci USA 103: 1255812563.

Valle J, Solano C, García B, Toledo-Arana A, Lasa I (2013) Biofilm switch and immune response determinants at early stages of infection. Trends Microbiol 21: 364-371.

Wolska KI, Grześ K, Kurek A (2012) Synergy between novel antimicrobials and conventional antibiotics or bacteriocins. Pol J Microbiol 61: $95-104$.

Wong KKY, Liu X (2010) Silver nanoparticles-the real "silver bullet" in clinical medicine? Med Chem Comm 1: 125.

Woodward JJ, Iavarone AT, Portnoy DA (2010) c-di-AMP secreted by intracellular Listeria monocytogenes activates a host type I interferon response. Science 328: 1703-1705.

Xu X-HN, Brownlow WJ, Kyriacou SV, Wan Q, Viola JJ (2004) Realtime probing of membrane transport in living microbial cells using single nanoparticle optics and living cell imaging. Biochemistry 43: 10400-10413.

Zhang Y, Hu Z (2013) Combined treatment of Psendomonas aeruginosa biofilms with bacteriophages and chlorine. Biotechnol Bioeng 110: 286295. 